\title{
MRC research centre under threat from London health service plans
}

London. A question mark has been placed over the future of a multimillion pound flagship biomedical research centre being built by the Medical Research Council (MRC) and the Wellcome Trust by uncertainty over the reorganization of London's teaching hospitals.

The MRC has already spent $£ 13$ million on the construction of a five-storey building to house its new Clinical Sciences Centre (CSC) at the Royal Postgraduate Medical School (RPMS), at Hammersmith Hospital.

The Wellcome Trust has agreed to invest an additional $£ 4$ million to pay for the construction of one floor of the building, due for completion in March 1994. Wellcome has also promised to provide programme grants to five scientific teams.

But the government is now proposing to merge the clinical services of the Hammersmith Hospital with those of the Charing Cross Hospital. The merger will form part of a larger streamlining of clinical services in London as part of the introduction of a full internal market in the National Health Service.

If the decision is made to close Hammersmith, its research laboratories would have tal, about three miles away. Such a move would not take place for several years. But hospital officials are worried that it would to move to the site of Charing Cross Hospi-

create a 'blight-and-flight' syndrome as grant-awarding bodies become reluctant to commit further funds to the centre, and scientific staff seek more secure positions elsewhere.

The MRC is planning to use the Hammersmith site to re-house laboratories from its Clinical Research Centre (CRC) in north London, which is due to close by the end of 1994. Tenured contracts have already been awarded to a number of CRC team leaders and other leading biomedical research workers from Britain and abroad.

Management consultants KPMG Peat Marwick have been assessing both hospital sites. They are due to report to a steering committee representing the London Implementation Group, the body set up by the government to advise on future plans for London's hospitals, by 20 October. This group is itself due to make recommendations to the Health Minister, Mrs Virginia Bottomley, by the end of the year.

According to figures presented to the steering committee's project group last Friday ( 1 October), the cost of transferring research activities from the Hammersmith to Charing Cross Hospital sites, which are already cramped for space, would be about $£ 105$ million. In contrast, moving clinical services from Charing Cross to Hammersmith Hospital would cost $£ 55$ million.

\section{NSF funds switched to facilities}

Washington. The National Science Foundation, the main government agency for the funding of engineering and the physical sciences in US universities, will receive a seven per cent increase in its budget in the financial year beginning this month. The total will rise from $\$ 1.86$ billion last year to $\$ 1.99$ billion.

Final figures agreed by Congress last week will trim $\$ 220$ million from the research funding requested for the NSF by the Clinton administration. This will allow the budget for new facilities and instruments to double in the coming year, from $\$ 50$ million to $\$ 100$ million.

The increase for buildings and equipment was agreed in a conference between House and Senate representatives on the section of the administration's budget bill which funds NSF and NASA. It reflects a growing feeling in Congress that agencies such as NSF should be given adequate funds for new research facilities to avoid universities having to rely on "earmarked" projects pushed through by friendly congressmen. The NSF will invite proposals from univer- sities this winter for projects on which to spend the new money.

A proposal by the Senate side that the NSF's request for High Performance Computing and Communications (HPCC) should be cut back by $\$ 50$ million was scaled down in conference. As a result, HPCC funding will now grow sharply to $\$ 305$ million, against $\$ 225$ million last year.

Language in the Senate version of the bill, which criticizes the NSF for its emphasis on pure research and calls for 60 per cent of its funds to be spent on so-called "strategic research," will remain in place. However, the language is not binding on the foundation.

The appropriations bill, one of thirteen disparate segments of the entire US budget now passing through Congress, allows the National Aeronautics and Space Administration (NASA) to spend $\$ 2.1$ on its planned space station next year. But it confirms the demise of SETI, NASA's small but controversial programme to seek out extraterrestrial life (see Nature 365, 380; 1993).

Colin Macilwain

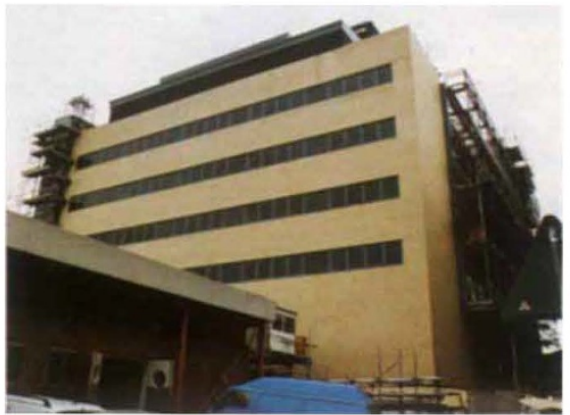

The new centre is to open in 1994, but for how long?

Neil Gershon, secretary of the RPMS, says that Hammersmith offers more than just financial advantages. In particular, it has room to expand into playing-fields behind the hospital, and is already engaged in a new phase of building and investment in modern clinical facilities.

Political factors, however, could favour the Charing Cross Hospital site, which was opened in 1972. It is easier to reach by public transport than the Hammersmith site and falls within a political constituency with a slim conservative majority. Closure of the Hammersmith site is also thought to be favoured by the North West Thames Regional Health Authority.

Kay Davies, professor of genetics at the Institute of Molecular Biology in Oxford, who has been appointed director of the $\mathrm{CSC}$, remains optimistic about the future of the centre. Even if the Hammersmith is relocated to Charing Cross, she says, the need to obtain planning permission and construct new facilities will delay any move until after the CSC is well-established. "Even if the worst scenario happened and we had to move in five or six years time we would already be flying".

But David Evered of the MRC admits that a second move would be highly disruptive for research teams. "If the outcome was such as to require a relocation, that would inevitably cause perturbation in the system," he says. If the move does take place, he says, it would be "an absolute prerequisite that certain conditions were met".

The Wellcome Trust had been expected to make final decisions on a number of matters, including the appointment of research teams to occupy the fourth floor, in September. But it is not now planning to make final decisions on appointments until November.

Davies says that Wellcome is right to be cautious. "I'm sure they won't want to fund things on this site unless they believe it's safe", she says. The trust itself has declined to comment.

Julie Clayton 